\title{
The Impact of the Crisis - Decline and Recovery
}

\author{
Joseph J. Stern \\ CID Working Paper No. 103 \\ January 2004
}

(C) Copyright 2004 Joseph J. Stern and the President and Fellows of Harvard College
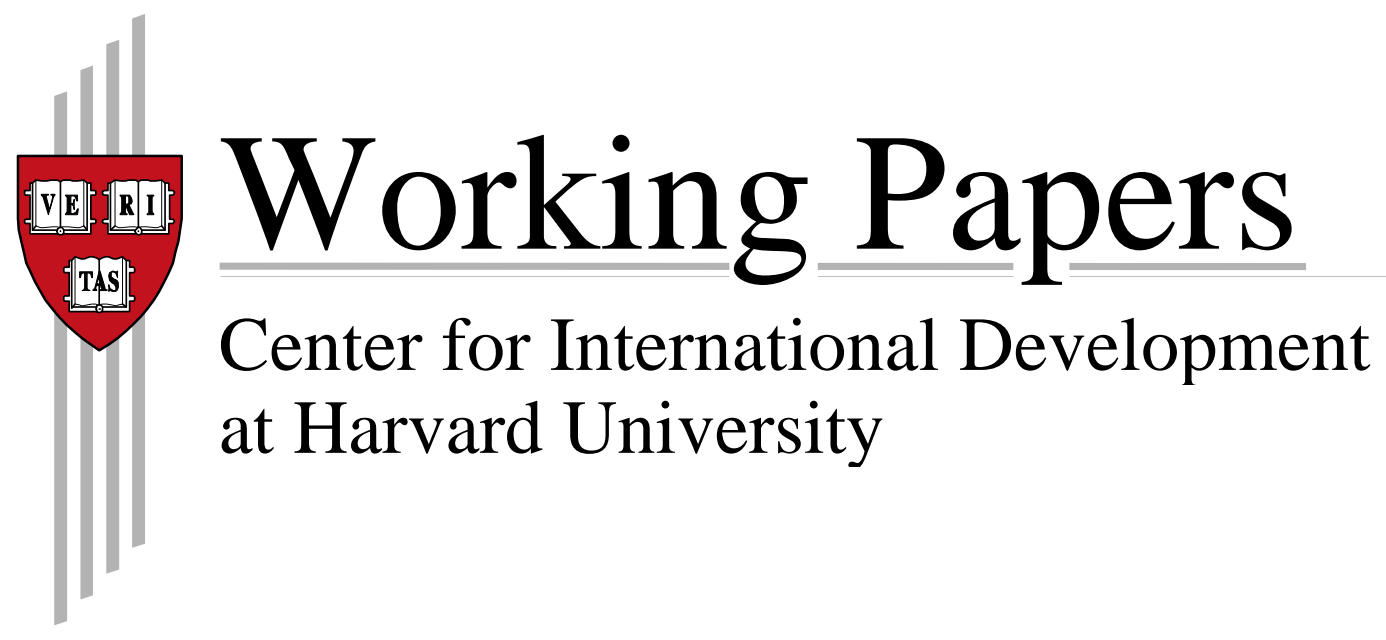


\title{
The Impact of the Crisis - Decline and Recovery
}

\author{
Joseph J. Stern
}

\begin{abstract}
When the Asian financial crisis broke in mid-1997, the expectation was that Indonesia would weather the crisis with minimal damage. Actual events soon proved these expectations widely wrong and the Indonesian economy was more severely affected than other Asian countries. In part this outcome reflected Indonesia's fundamental institutional weakness that had been overlooked in the euphoria that marked international financial markets during the 1990s, and in part the impact of the financial crisis was magnified by inconsistent internal policies and by an overly ambitious IMF program that tried to achieve too much in to short a period of time. The result was not only a severe economic contraction with rising poverty levels and growing social unrest, but a political change that resulted, in the short-run, in further economic instability and effectively delayed Indonesia's recovery.
\end{abstract}

Keywords: Indonesia; Asian financial crisis; currency board; IMF conditionality; bank failures; political change.

JEL Codes: O11, O19, 024, O53; N25

Joseph Stern is a Lecturer on Public Policy, John F. Kennedy School of Government, and an Associate of the Center for International Development. He served as an economic adviser to the Ministry of Finance, Indonesia, from 1990 - 1994 and from 1996-1999. 
Draft: For comments only Not for quotation or attribution

\section{The Impact of the Crisis - Decline and Recovery* \\ Joseph J. Stern \\ John F. Kennedy School of Government Harvard University}

Introduction: The crisis unfolds.

During the three months period July through September 1997, the Asian financial crisis gathered full force and began to affect Indonesia despite continued expression of confidence that the soundness of its economic fundamentals and its economic management would see it through with little damage. By the end of the year these assumptions had been found wanting.

At the end of June, the Laporan Bulanan Makroekonomi, the monthly economic report prepared in the Ministry of Finance, could still report that "[d]espite the uncertainty associated with the recent [Indonesian] elections [held on May $29^{\text {th }}$ ] and the economic turmoil in both Thailand and the Philippines, neither the foreign exchange market nor [the domestic] interest rates showed any significant movement. ${ }^{1}$ Indeed, the report went on to state that interest rates showed a marginal decline during the month, while the rupiah continued to trade near the appreciation edge of the intervention band while inflation continued to decline. The only negatives highlighted in the report were the continued decline in world oil prices and the sluggish growth in Indonesia's non-oil exports. As regarded the latter issue, the report went on to stay that "...there is considerable evidence that domestic policies have reduced Indonesia's competitiveness and have made Indonesia less attractive as a possible export platform."

On July 2, 1997, just two days after the monthly economic report was completed, the central bank of Thailand was forced to abandon its fixed exchange rate regime and the baht immediately depreciated by almost $20 \%$. These developments gave substance to the long-standing informal reports of structural problems and weaknesses in the Thai economy. But even more troublesome, the developments in Thailand led to a sudden re-

\footnotetext{
* The assistance of Constantin C. Crachilov is gratefully acknowledged.

1 Laporan Bulanan Makroekonomi Juli 1997 (Monthly Economic Bulletin for July 1997) June 30, 1997.

2 Ibid.
} 
assessment of the commonly held belief that the rapidly growing Asian economies were immune to a "Mexican style" economic meltdown. Analysts now began to speculate that if the "Asian miracle" had been oversold then the very large private capital inflows of the previous years were based on unfounded optimism so that the optimistic assessments were suddenly replaced by an increased feeling of skepticism about the health of the Asian economies. As questions began to be raised about the structural soundness of the East Asian economies there was a sudden and dramatic reversal of capital flows as inflows turned into massive capital outflows and banks that were once eager to lend to nearly any Asian investor suddenly refused to renew short-term credit lines. ${ }^{3}$ Pressure soon rose against the Malaysian ringgit with Bank Negara Malaysia reportedly spending $12 \%$ of its foreign exchange reserves (roughly $\$ 4$ billion) in a futile attempt to defend the currency. Eventually the ringgit depreciated by $4 \%$.

A similar situation emerged in the Philippines where on July 11 the central bank announced that it could no longer defend the peso and moved to a floating currency regime. The peso quickly lost $12 \%$ of its value. The same day Bank Indonesia, hoping to stem the pressure on the rupiah, widened the exchange rate band from $8 \%$ to $12 \%{ }^{4}$ If further evidence of a change in perceptions was needed it came immediately. Previously, when the band had been widened the result was a rapid inflow of capital, forcing the central exchange rate to the appreciation edge of the band; this time the rupiah depreciated. ${ }^{5}$

\footnotetext{
3 Soedradjad, referring to an Institute of International Finance estimate, notes that there was a reversal of capital flows in to the five affected Asian economies - Korea, Thailand, Malaysia, the Philippines and Indonesia - of \$105 billion from 1996 to 1997. For Indonesia, the estimated capital inflows in 1996 were about $\$ 10$ billion while in 1997, primarily in the latter half; there was an outflow in 1997of $\$ 12$ billion, for a total reversal in capital flows of some $\$ 22$ billion. See J. Soedradjad Djiwandono (April 2000) "Bank Indonesia and the Recent Crisis," Bulletin of Indonesian Economic Studies, 36(1) pp. 49.

4 Another lesson from the wave of currency depreciations that swept over Southeast Asia was that the repurchase agreements that had been set up after the Mexican crisis proved inadequate to fend off currency attacks. This reflected the fact that the help expected under the repurchase agreements was too slow to provide instantaneous relief and that some central banks (for example the central bank of the Philippines) possessed inadequate US Treasury securities to cover the foreign exchange required.

5 Morris Goldstein has labeled the phenomenon where the weakness in one country quickly leads to negative outcomes in neighboring countries as the "wake up call" hypothesis. He argues that individual investors who either behave irrationally or refuse to pay the mounting costs associated with acquiring the correct information with which to asses an individual country, proceed to move out of countries that share some characteristics of the crisis country, thus providing a rationale for the contagion affect of the crisis. See Morris Goldstein, The Asian Financial Crisis. Washington, D.C.: Institute for International Economics, 1998.
} 
On Friday, July $18^{\text {th }}$, the rupiah weakened by $1.3 \%$, falling from Rp $2,477 /$ US $\$$ to Rp 2,510/US\$. Worse was to follow. Over the weekend a number of private Indonesian companies, seeking cover for their dollar-denominated debt, purchased foreign exchange on overseas markets, leading to a large overnight shift in the exchange rate and a sharp reaction from domestic participants who, when the onshore markets opened on Monday, suddenly confronted an exchange rate that had moved dramatically against them. By the end of the trading day on Monday, July 21, the rupiah had fallen to a low of $\mathrm{Rp}$ 2,670/US\$ before closing at Rp 2,506/US\$, a loss of almost 6\%. Although Bank Indonesia intervened in the market, first by selling dollars forward and then in the spot market, these efforts had little impact on the rupiah's longer-term value. But they did result in a decline of foreign exchange reserves of some $4.6 \%$ during July, the first substantial decline in reserves Indonesia experienced in many years. The available data suggest that during the last half July and the first half of August Bank Indonesia spent some $\$ 1.5$ billion in support of the currency. While the fall in the rupiah's value began to cause difficulties for many part of the real economy and raised difficult macroeconomic policy issues $^{6}$, it had positive outcome: the nominal depreciation returned Indonesia real exchange rate to levels not seen since the late $1980 \mathrm{~s}$.

By Wednesday, August 13, the rupiah was trading near the top of the intervention band and given the choice between gambling large amounts of its foreign exchange reserves in an effort to defend the band or raising interest rates to ever-higher levels, with the inevitable damage to the financial sector and the real economy, Bank Indonesia abandoned its long-standing commitment to a crawling peg. On August 14, 1997, the rupiah was set free to find its own rate, the last of the regional currencies to abandon efforts to fix the exchange rate. The move to a floating rate was widely applauded by the international financial community but it proved to be an ineffective step in containing the coming economic and political onslaught.

With the intervention band removed the rupiah, which had been trading in a fairly stable range of Rp 2,580 to Rp 2,620/US\$, began to lose value. Trading on the foreign exchange market opened on August $14^{\text {th }}$ at $\mathrm{Rp} 2,650 / \mathrm{US} \$$ but by the end of day the

\footnotetext{
${ }^{6}$ The impact of the evolving crisis was dramatically brought home by the sudden cessation of nearly all construction activities. Large construction cranes which dotted the Jakarta skyline and which had been active just a few days before, were suddenly frozen and remained unmoved for the next three years.
} 
rupiah had weakened to Rp 2,800/US\$. Over the next few days the currency continued to depreciate and on August $19^{\text {th }}$ crossed what some felt was a psychologically important level, Rp 3,000/US\$. Concerned about the abrupt weakening of the rupiah Bank Indonesia took action to drain liquidity from the banking system, raising interest rates sharply. State-enterprises were instructed to withdraw deposits from commercial banks and deposit such funds in the central bank. ${ }^{7}$ The interest rates on one-month SBI certificate (Sertifikates Bank Indonesia) rose from 12\% to 30\% while the three-month rate rose from 11 to $28 \%$. Between August 19 and 21 the overnight inter-bank rates shot up to over $100 \%{ }^{8}$ As expected these steps contracted liquidity and led to a sharp drop in the demand for dollars so that by August 21 the rupiah had recovered to Rp 2,700/US\$.

But these monetary measures also put tremendous pressure on the weaker banks and by the end of August some 50 banks failed to comply with the minimum 5\% reserve requirement. Although the rupiah continued to trade in the relatively narrow range of Rp 2,650 to $\mathrm{Rp} 2,750 / \mathrm{US} \$$ over the next few days, by August 29 rumors began to circulate that interest rates would soon be lowered, presumably to ease pressures on the banking system.. The rupiah immediately began to weaken once again crossing the Rp 3,000/US\$ mark. Despite the stated policy of tightening the money supply, a step that some analysts have subsequently criticized, interest rates fell throughout September as Bank Indonesia reversed policy and began to inject liquidity in to the market. On September 4, Bank Indonesia lowered the three-month SBI rate to $25 \%$ from the previous level of $28 \%$ and on September 9 further lowered the rate to $23 \%$ and to $21 \%$ on September 15. For the month as a whole the SBI rate fell by one-third. In addition the overnight inter-bank loan rate, perhaps the best indicator of system wide liquidity, fell from its September 16 level of $38.4 \%$ to $19.0 \%$ at the end of the month. In other areas policy actions also became less clearly focused. For example, on September $3^{\text {rd }}$ the government had announced that a number of large, and economically questionable, infrastructure projects, largely opposed by the economic technocrats, would be postponed. But subsequently President Soeharto suggested that the postponed projects could proceed after all, provid-

\footnotetext{
${ }^{7}$ Bank Indonesia also began to enforce statutory reserve requirements more strictly (but far from completely) further reducing the liquidity of the banking system.

${ }^{8}$ Soedradjad, op cit., reports that there "was even an occasion when the overnight interbank rate reached $200 \%$ per annum." (p. 52).
} 
ing further evidence that the technocrats were no longer fully in control. And even though in early September the government had announced further economic reforms and deregulation measures, including a commitment to renewed effort to strengthen and enforce bank prudential regulations, the initial announcements were not followed by implementation decrees, providing further evidence that the government was no longer unified on measures needed to stem the impact of the crisis. The markets now realized that the deregulation program would not regain its dynamism any time soon ${ }^{9}$. Analysts began to question whether the government had the political will to carry through on the needed reforms. While no one believed that the reforms would immediately stem the crisis, many argued that proceeding with the reform agenda was an important indicator of Indonesia's commitment to further global integration and a step that help it regain some measure of international confidence and support.

In response to these policy inconsistency at the end of September the rupiah suddenly depreciated by $20 \%$ in one week. Indeed during September the rupiah began to weaken more rapidly than the currencies of the other Asian crisis affected economies, as shown in Table 1.

\section{Table 1}

Depreciation of East Asian Currencies

(June 30 - October 3, 1997)

Exchange Rate

(Local currency/US dollar)

Currency June 30 August 29 $\underline{\text { Sept. 25 }}$

1. Rupiah $2,432.00$

$2,900.00$

2.525

26.38

24.90

1.430

2.891

30.40

34.15

1.501

$3,035.50$

3.125

33.45

34.95

1.520
June 30 to Aug. 29 to Sept. 25 to

Oct. 6 $3, \overline{717.50}$

3.260

35.20

36.10

1.552 $\underline{\text { August } 29}$ Sept. $25 \quad$ Oct. 6 $19.2 \% \quad \frac{5}{4.7 \%} \quad \frac{0 c t .6}{225 \%}$

$\begin{array}{lll}14.5 & 8.1 & 7.6\end{array}$

$\begin{array}{lll}15.2 & 10.0 & 5.2 \\ 37.2 & 2.3\end{array}$

$\begin{array}{lll}37.2 & 2.3 & 3.3\end{array}$

Source: Laporan Bulanan Makroekonomi (Monthly Economic Report) various issues, prepared by the Economic Analysis Unit, Ministry of Finance, Jakarta.

On October 8, 1997, two days after another sudden sharp fall in the rupiah's value, Indonesia requested assistance from the International Monetary Fund, the World

\footnotetext{
${ }^{9}$ In addition to the already mentioned postponement of major infrastructure projects, there was to be a scaling back of development programs, an extension of the luxury sales tax, and import duties on over 150 items, mainly raw materials and other intermediate goods, were to be reduced effective mid-September.
} 
Bank, and the Asian Development Bank, as well as financial support from Singapore, Japan, the United States and other regional economies. The IMF quickly responded and a team was sent to Jakarta to work out the details of a stand-by arrangement.

From IMF to Currency Board.

At the beginning of November the IMF announced agreement on a standby agreement that included a $\$ 23$ billion financial package identified by Managing Director Michel Camdessus as a "first line of defense." There was also a so-called "second line of defense" although uncertainty surrounded its actually size and the conditions under which it could be tapped. ${ }^{10}$ When, even after the intervention by the IMF, the currency continued to weaken and economic activities began to contract sharply, this program became the subject numerous reviews and critiques. But that was still to come. Initially the program seemed to offer some relief. On Monday, November 3, the first working day after the announcement of the IMF agreement, the rupiah appreciate by almost $10 \%$. In fact this improvement was mainly on the basis of a well-coordinated intervention by the central banks of Indonesia, Japan and Singapore and this initial success proved ephemeral. In retrospect it appears that the financial markets had concluded that the actual size of the program was insufficient to stabilize the exchange rate and there was considerable skepticism whether there was sufficient political support to effectively implement the IMF program.

The question of whether the government would, and indeed could, effectively implement some of the measures called for in the agreement was soon put to the test when the central bank moved to close 16 banks. That there were many weak banks, whose balance sheets had been further weakened by the onset of the financial crisis, was no secret so

\footnotetext{
${ }^{10}$ There was in fact considerable confusion about the actual size of the IMF's package. First, the package counted some $\$ 5$ billion of Indonesia's own reserves that were supposedly set aside in support of the program. The so-called "second line" facilities, which included contributions from Japan, Singapore, the USA, Malaysia and Australia, were estimated to total some $\$ 15$ billion although in some reports this was given as a larger amount. Cf. J. Soedradjad Djiwandono (1998). "Monetary Policy and the Banking System in Indonesia: Some Lessons." Fifth Indian-ASEAN Eminent Persons Lecture, New Delhi, India (September 12. The confusion was further compounded by the uncertainty about whether Singapore's contribution was US $\$ 5.0$ billion or only Singapore $\$ 5.0$ billion or even as some suggested, Singapore $\$ 10$ billion. Cf. Lloyd R. Kenward, (May 1999) "From the Trenches: The First year of Indonesia's Crisis of 1997/98 as Seen from the World Bank's Office in Jakarta." Unpublished manuscript.
} 
that it was no surprise that a number of banks were to be closed. ${ }^{11}$ In light of subsequent developments it should also be noted that even before the bank closures were announced there had been a flight to safety, with many depositors taking their money from private banks and placing them in state-banks that were perceived to be safe, even if they were no better managed. But the press discussion about the likelihood that a fairly large number of banks might be closed had two unintended and highly negative consequence. Some analysts now argued that since only 16 banks were closed, the IMF had in fact caved in to the political power of the crony capitalists who, together with the President's children, had managed to protect the many other weak banks in which they had significant stakes. ${ }^{12}$ Other analysts pointed out that since only 16 banks were closed there would be a second wave of bank closures. ${ }^{13}$ The result was that depositors were not persuaded either that the government would now enforce prudential regulations or that the banking system was safe. In fact Cole and Slade argue that this action led to the "...undermining [of] confidence in all private banks, and participat[ed] an open political confrontation between the President's family and the Minister of Finance and Governor of the Central Bank." They concluded that "the President's family won that battle but in the process caused serious loss of confidence in Indonesia's future, and immediate loss of effectiveness of the technocratic ministers." 14 Soedradjad Djiwandono, central bank governor at the time, concluded that the closing of the banks "... a step which was designed to return confidence to the banking sector instead resulted in the collapse and confidence which plunged the banking into chaos." "15 In retrospect it seems doubtful that even under the best of circumstances the closing of the 16 banks would have had much of a stabilizing effect and the most immediate effect of the closing was to accelerate the flight to safety.

${ }^{11}$ Various newspapers published supposedly "authentic" lists of so-called "problem banks," fueling public anxiety, with some going so far as to suggest that close to half of all banks would be shut.

12 The fact that a son of the President owned one of the 16 banks (Bank Andromeda) and that another was owned by the President's half brother did little to reassure the markets about the seriousness of this action. ${ }^{13}$ The first standby specifically mentions that "...10 banks that have contractual agreements ...to implement rehabilitation programs [but] ...that have not returned to solvency will be closed by the end of 1998." IMF First Standby Agreement, op cit., par. 43, p. 17. It is difficult to say how widespread this information was among the general public, since the first standby was initially not made public but rumors that there would be further bank closings were a daily occurrence.

${ }^{14}$ David Cole and Betty Slade (1998) “Why Has Indonesia's Financial Crisis Been So Bad?” Bulletin of Indonesian Economic Studies., Vol. 34 (2), pp. $61-66$.

${ }^{15}$ Soedradjad Djiwandono, op cit., p. 10. 
Whatever ones final reading on the decision on the initial bank closures, it should be noted that Bank Indonesia and its staff managed this step with reasonable efficiency. In parallel with the announced closure of the 16 banks, the government promised that all small depositors, those holding Rp. 20 million or less, would be fully compensated and some 800,000 small depositors were in fact quickly paid off. ${ }^{16}$ Perhaps more important, in light of later developments in the banking crisis, the government did not guarantee repayment but asked Bank Indonesia to use its own funds to pay out the small depositors with an advance that the government would finance until it could establish a deposit insurance scheme. ${ }^{17}$

The crisis now entered a new stage. As the rupiah continued to weaken deposits fled from banks perceived to be weak to safer havens - either by converting rupiah into dollars or by shifting deposits to foreign owned banks or to the state-banks. ${ }^{18}$ The result was that an increasing number of private domestic banks began to face severe liquidity problems. In August reserves held by commercial banks with Bank Indonesia fell from $\mathrm{Rp} 11.9$ trillion to $\mathrm{Rp} 4$ trillion although the estimated required reserves were around $\mathrm{Rp}$ 12.5 trillion. During September commercial banks managed to raise their reserve levels but they did so largely by borrowing from a special discount window that Bank Indonesia had activated. By September Bank Danamon and BDNI, two of the largest private banks, had already lost half of their dollar deposits and the use of liquidity reserves was increasing. It was during August and September that Bank Indonesia began to accommodate banks whose reserves had fallen below their required levels by allowing them to continue to participate in the daily clearing, effectively providing some measure of liquidity support. And the President managed to further cloud the situation by announcing, shortly

\footnotetext{
${ }^{16}$ Small depositors had to wait about two weeks to be fully paid off while other depositors had to wait till the banks were liquidated and all tax obligations settled before they would be paid off.

17 The first standby agreement stated that "...once the situation stabilizes and the banking system is on sounder footing, Bank Indonesia will institute a formal deposit insurance scheme covering private and public banks." Par. 49, p. 18. International Monetary Fund, Indonesia: Request for a Stand-by Arrangement. October 31, 1997.

18 At one time Bank Indonesia nearly ran out of currency but managed to meet demand by locating a number of boxes held in storage that contained commemorative Rp 50,000 bank notes that had been printed for Indonesia's fiftieth independence day in 1995.
} 
before leaving for an overseas trip, that the government would not close any more banks in the future. ${ }^{19}$

Given this policy signal, Bank Indonesia felt it had no choice but to increase the amount of liquidity support to illiquid banks, further loosening its monetary controls as it tried to prevent a widespread collapse of the banking system. The result was a rapid rise in liquidity support, which rose sharply throughout the last quarter of 1997 and continued to rise well into 1998, as shown in Figure 1. The liquidity support funds, provided with few or no controls, fueled an ever-larger demand for dollars, further weakening the currency and leading to an even larger demand by banks for liquidity support. The sharp increase in liquidity resulted in a deterioration of the macroeconomic situation and worsened the increasingly acrimonious debate between the government and the IMF about how to contain the crisis.

Figure 1

Indonesia Liquidity Support

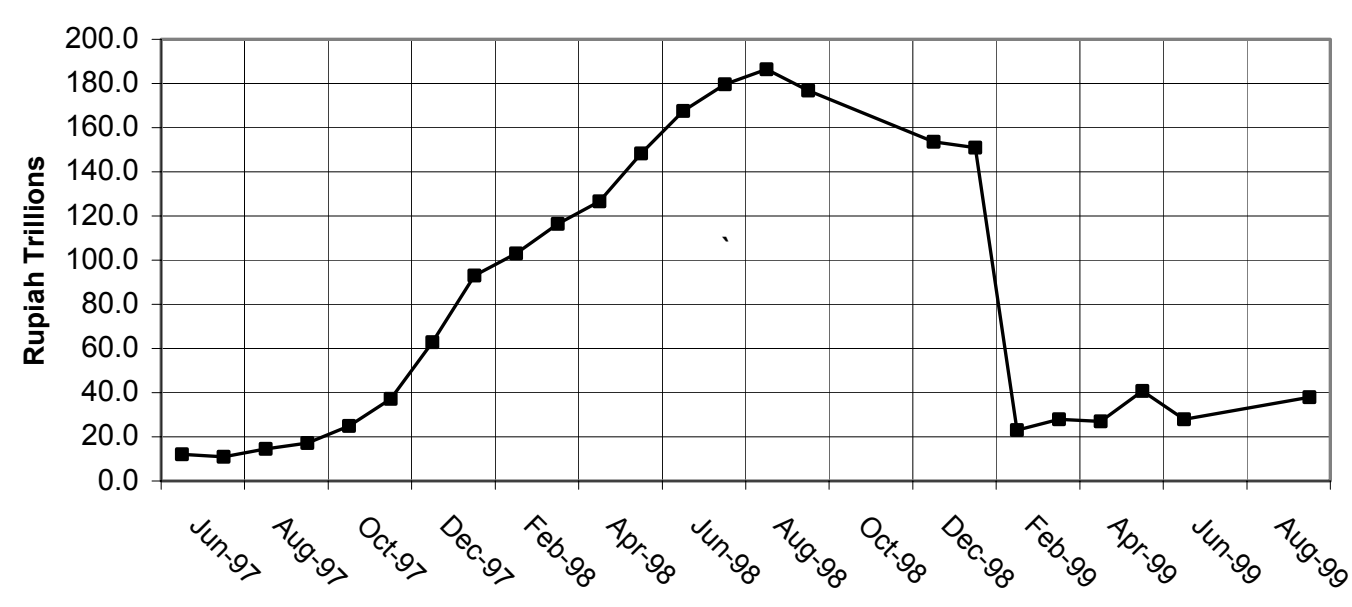

Bank Indonesia data, various documents.

In the aftermath of the financial crisis, two questions have been raised. First, what justification was there for Bank Indonesia to provide such large-scale liquidity support? Second, was the closing of the 16 banks a "mistake" that in effect set of the bank run and worsened, rather than helped ameliorate, the crisis? The extent to which Bank Indonesia was forced by political pressures to rescue potentially failing banks without

19 J. Soedradjad Djiwandono. "Bank Indonesia and the Recent Crisis." Bulletin of Indonesian Economic Studies. Vol. 36 (1) April 2000, p. 63. 
raising to many questions is an issue that remains unclear. Even if one cannot provide a definitive answer it seems reasonable to conclude that the use of liquidity funds, which undoubtedly contributed to the ongoing pressure on the rupiah, had to be provided given the President's implicit instructions that he did not want more banks to be closed, at least in the near term. Yet even if one recognizes the difficult situation created for Bank Indonesia management by the President's stand, it may be correct, as some allege, that Bank Indonesia management violated its own regulations by issuing liquidity support without adequate safeguards in terms of receiving access to high quality assets and charging high interest rates. Bank Indonesia officials have countered that the central bank “...was forced by its call of duty and the government policy, to help many banks that suffered from liquidity crisis..."

It is perhaps correct that facing these constraints there was little Bank Indonesia could do but try and keep the illiquid and insolvent banks afloat although the anger by some at the perceived misuse of public funds to safeguard the interest of a few well connected private individuals is also easily understood. Given the ethnic divisions in Indonesia many view the use of liquidity support as a way of helping a number of large Chinese owned banks to survive and in the process making it possible for many of the Chinese capitalists to convert their rupiah held assets to dollars. ${ }^{21}$ Indeed the Supreme Audit Agency $(B K P)$, in a report commissioned by the House of Representatives in 2000, found that Rp. 138 trillion of the $B L B I$ funds issued during 1997 - 1999 were misused by the recipient banks, most of which were owned by cronies or relatives of Soeharto. ${ }^{22}$ The issue of whether Bank Indonesia management should have behaved differently and with what economic and social impact will not be easily resolved.

In trying to understand Indonesia's eventual economic collapse, some have noted that in moments of severe crisis, when there is a daily prospect of a widespread systemic bank failure, there is little time to seek policy clarification and explore alternative policy

\footnotetext{
20 Soedradjad Djiwandono, “Controversial Issues." Unpublished manuscript.

21 The Indonesian term for these liquidity support measures is Bantuan Likuiditas Bank Indonesia, or $B L B I$.

22 The government initially refused to cover the $B L B I$ losses, a move that threatened to bankrupt Bank Indonesia. In November 2000 the Finance Ministry and Bank Indonesia eventually reached an agreement under which the bank would only have to cover Rp 24 trillion, while the government's Bank Restructuring Agency $(I B R A)$ would assume responsibility for the remainder.
} 
approaches. Moreover, it also needs to be noted that Indonesia's banking crisis and economic meltdown played itself out against a growing unease with the political and economic situation. In the face of the determined effort by the ruling party to retain its hold on political power and provide continued economic protection not only to the immediate family members but also to the crony capitalist it is unlikely that any effort at stabilizing the economy, no matter how well executed, would have been successful. ${ }^{23}$

In fact it now became common in Indonesia to vacillate on economic matters. On November 8 President Soeharto issued a decree allowing the implementation of the 15 projects previously put under review or postponed, a move that was widely perceived as a significant back tracking from earlier commitments. Other contradictory statements and decrees raised further concern that there was no clear economic view on how to deal with the crisis. In this light it is probably fair to conclude that while the closing of 16 banks may not have been well thought out or well implemented it was not the only cause, or perhaps even the major cause, of the subsequent collapse of confidence in the banking system.

In mid-November came the news that the Korea won was also under severe pressure. The realization that even Korea, a newly admitted member to the OECD and one of the original "Asian miracle economies," might not weather the crisis unscathed further fueled the financial panic. On November 15, Seoul was forced to stop foreign exchange trading for the third consecutive day when, half an hour after the trading day began, the won reached its allowed limits for daily fluctuations. Korea, following on the heels of Thailand and Indonesia, quickly turned to the IMF for assistance. The realization that Korea too could not withstand the onslaught of the financial crisis raised the level of panic among investors throughout Asia.

Adding to this mix, rumors began to emerge in early December that the President Soeharto was in poor health. After completing a trip to South Africa, followed by a visit

\footnotetext{
${ }^{23}$ Consider for example that Thailand not only changed government during this period but also adopted a new constitution, a process that admittedly was underway before the crisis broke, while Korea held its scheduled elections soon after the crisis reached its shores, and affected a change in government. These changes in government leadership may have been coming in any event but they gave the impression that in both countries there was now a new government ostensibly committed to reforms and better economic management. No such change in government took place in Indonesia nor was any regime change anticipated.
} 
to Canada to attend the annual APEC meeting, with a return journey that involved a brief visit to Saudi Arabia, doctors told Soeharto that he had to take ten days of rest. This, given the President's age, was perhaps not totally surprising, but when the President was also forced, at the advise of his medical team, to cancel a planned trip to Iran, where he was scheduled to attend a meeting of the Organization of Islamic Conference, concerns deepened. Even more disturbing was the news that the President would also cancel his trip to Kuala Lumpur, where he was to attend an ASEAN meeting, a trip that required only a short ninety-minute flight. All of these events contributed to the continued slide of the rupiah which fell to Rp. 5,015/US\$ on December 12 while the Jakarta stock market closed at a four year low.

At the end of December the government announced that by mid 1998 four stateowned banks (Bank Dagan Negara, Bank Bumi Daya, Bapindo and Bank Ekspor Impor) would be merged, in line with its commitment under the IMF's Letter of Intent. At the same time the Minister of Trade and Industry announced a ban on the exports of crude palm oil, which was to remain in, place least through the first quarter of 1998 . This measure was taken in response to the sharp rise in domestic prices as palm oil producers shifted from meeting the needs of the domestic market to exploiting the higher prices now available on the international markets. While the Minister's concern about rising domestic palm oil prices, especially as the end of year festivities gathered force, was understandable, it again raised the question of Indonesia's commitment to increasing the scope for market determined economic outcomes. Yet despite the various pieces of negative news - including the severe and largely unchecked forest fires that caused considerable friction between Indonesia and its neighbors, all of whom were affected by the heavy smoke pollution, as well as the persistent drought which severely eroded agriculture output throughout the region - the year ended with the currency strengthening to Rp. $4,800 /$ US\$. This good news however did not reflect market sentiment but was the result of substantial intervention in the foreign exchange markets by Bank Indonesia, which wanted to create a reasonably strong exchange rate for companies that closed their books at the end of the calendar year. Not surprising then that on January 2, 1998, the first trading day of the New Year, the rupiah resumed its downward slide, falling to Rp. 6,200/US\$. 
On January $6^{\text {th }}$, the government announced its 1998/99 - draft budget which was based on assumptions that were quickly derided as unrealistic and in violation of the IMF agreements. $^{24}$ The result was a further loss of international confidence in the government leading to another significant weakening of the rupiah, which reached Rp. 8,100/US\$ on January 7 , bringing the cumulative depreciation since the onset of the crisis in July to 70 percent - by far the largest depreciation among the affected Asian economies. On January 15, 1998 a second IMF package was announced. In response to the growing concern by the IMF shareholders that Indonesia failed to live up to is commitments under the earlier agreements, the January letter of intent provided a detailed item by item deadline for the implementation of numerous policy reforms, including the commitment to " ...adjust administered prices with the aim of gradually eliminating subsidies on fuel and electricity." ${ }^{25}$ Eventually it was the President's decision to meet this specific target that ignited the disturbances, which brought about a change in government.

Although much of the period since the signing of the first IMF agreement had been marked by policy inconsistencies the government finally undertook a series of step intended to restore some measure of economic calm. On January 26 the Indonesia Bank Reconstruction Agency (IBRA) was established and assigned the task of taking over and managing insolvent banks. At the same time, in a somewhat surprising step, the government announced a 100\% deposit guarantee scheme covering all bank liabilities including inter-bank debt and debt to foreign banks. The decision to provide a 100\% deposit guarantee scheme not only created a potential future moral hazard but also sharply increased government liabilities since the government now assumed the cost of the bank recapitalization efforts. ${ }^{26}$ The immediate impact however was to stem the bank runs and restore some measure of confidence in the local currency. ${ }^{27}$

\footnotetext{
${ }^{24}$ The draft budget assumed revenue and expenditure growth of $31.1 \%$ over the previous budget, widely perceived as breaking the IMF targets, while GDP growth was set at $4.1 \%$ with inflation projected to below $10 \%$ for the year despite the already massive depreciation of the currency and the widespread havoc this had already caused to the real sector.

${ }^{25}$ The process of eliminating fuel subsidies "...while protecting the poor" was to start on April 1, 1998 but was to run the course over the program. IMF. Indonesia Memorandum of Economic and Financial Policies (January 15, 1998) p. 4.

${ }^{26}$ Given the eventual massive collapse of the Indonesian banking system the policy to guarantee all bank deposits in full remains a contentious issue. The IMF does note that at the end of January 1998 "...the authorities accepted the banking strategy proposed by the IMF ...[including a] a general guarantee scheme." [International Monetary Fund, Evaluation of the Role of the IMF in Recent Capital Account Crisis: Coun-
} 
On balance however, and despite the somewhat humiliating public ceremony showing President Soeharto signing the new letter of intent while Managing Director Michael Camdessus stood behind him arms akimbo, the government's commitment to a consistent reform process remained weak. Only a few days after the new IMF agreement had been initialed, the President stated that the National Car Project as well as the plan to develop an Indonesian jet-plane would continue, albeit without state funding. Then on January 20 the President stated that the next vice president should be a person well versed in modern technologies, a strong hint that Habibie, Minister of Technology and a leading proponent of a government led high-technology approach to development, was to be his next running mate. In response to this announcement the rupiah quickly weakened to Rp. 10,000/US\$. On Wednesday, January 28, 1998, the last day before the onset of the major holiday marking the end of the month long Ramadan fast, the rupiah traded at Rp. 11,150/US\$ although offshore trading saw the rupiah weaken to a record Rp. 12,050/ US\$. But surprisingly, on Monday, February 2, when onshore trading resumed, the rupiah opened stronger and gained strength throughout the day, ending at Rp. 10,550/US\$, up 5.4\% from the offshore low. Although the currencies of all the Asian economies affected by the crisis strengthen at this time in retrospect it seems that rumors about an impending move by Indonesia to adopt a currency board had already begun to seep into the markets and propped up the rupiah.

The emergence of the currency board as an alternative way of resolving the currency crisis now added a further complication to efforts to stabilize the economic situation and further damaged Indonesia's fading reputation for careful economic management. At the end of January, Professor Steve Hanke, a strong and vocal proponent of currency boards, arrived in Jakarta. Meetings were quickly arranged with the President and the senior economic ministers as well as with the Governor of Bank Indonesia and

try Annexes. April 11, 2003, p. 30-31] but whether the IMF's recommendation was meant to be as broad as the policy eventually put into place is unclear.

27 The economic crisis resulted in a major realignment in Indonesia's banking system. In June 1997, at the onset of the crisis, there were 237 banks; three years later this had shrunk to 161. More startling, whereas before the crisis only $37 \%$ of all deposits were held in state-owned banks, by June 2000 some $70 \%$ of all deposits were held by the state banks. See "Indonesia: Accelerating recovery in uncertain times." Washington, DC: The World Bank (October 13, 2000). 
members of the economic team. ${ }^{28}$ Eventually Professor Hanke was appointed adviser to the Indonesian Council for Economic and Financial Resilience, a group set up earlier by President Soeharto to help manage the economic crisis. ${ }^{29}$ During most of February much of the economic news revolved around the issue of whether Indonesia would, or would not, adopt a currency board. As Indonesia seemed to veer ever closer to the adoption of a currency board, the rupiah strengthened, at one point trading at around Rp. 7,000/US\$. But this was less a vote of confidence in Indonesia's ability to effectively implement a currency board then speculative movements by foreign exchange traders who stood to make enormous profits if Indonesia moved to a currency board regime and set the exchange rate at a rate stronger than the prevailing market rate.

In fact there never was any public statement about what exchange rate might be adopted although there was ample speculation that an exchange rate of Rp. 5,000/US\$ was under consideration. Most likely the assumption that the currency board would settle on a rate close to Rp. 5,000/US\$ reflected two related rumors. First, there was a belief that many of the corporations now reeling under the debt burden that the collapse of the rupiah imposed, could survive at an exchange rate of about Rp. 5,000/US\$, which was linked with the second rumor that Professor Hanke's visit had been facilitated by these very same industrialists. Given these assumptions it was easy to conclude that the rate to be adopted would be one that might save the tottering industrial empires of the President's children and the crony capitalists. ${ }^{30}$ However a number of analysts pointed out that pegging the currency at anything approaching that rate was no longer feasible and

\footnotetext{
${ }^{28}$ Like much of the history of the economic crisis the issue of who invited Professor Hanke to come and advise the government remains unclear although given the immediate access to President Soeharto and the senior government ministers that was accorded to Hanke it is save to conclude that his visit had substantial high level support. Cf. Steve H. Hanke, "How I Spent My Spring Vacation." The International Economy, Vol. 12 (4) July/August 1998. An alternative view was expressed on one of the informal website based newsletters emanating from Indonesia. For example as Laksaman.net reported "...the main backers of the currency board plan had been Bambang Trihatmodjo and his eldest sister Siti Hardiyanti, "Tutu" Ruksmana. Critics claimed the Soeharto children wanted the currency board to allow them to briefly stabilize the value of the rupiah long enough to allow them to convert their Indonesian accounts into dollars at a reasonable exchange rate." (May 30, 2002).

${ }_{29}$ J. Soedradjad Djiwandono. "Bank Indonesia and the Recent Crisis." Bulletin of Indonesian Economic Studies, Vol. 36 (1) April 2000, p. 64. Djiwandono's description of the currency board controversy (pp. 64 -66) is probably the most complete insider view on this issue available to date.

${ }^{30}$ A strong rate was certainly hinted at by Mr. Pieter Gontha, a business associate of Bambang Trihatmodjo, one of President Soeharto's children, who was quoted as saying: "Nothing the IMF has done has worked, so unless the IMF can come up with a better way to bring the rupiah down below 6,000, the currency board should be given a chance." Asian Wall Street Journal. (February 10, 1998).
} 
would certainly violate some of the fiscal and monetary measures only recently put in place. At the end of January 1998 base money totaled about Rp. 53 trillion which would require a foreign exchange cover of over $\$ 10$ billion if the exchange rate was set at Rp. 5,000/US\$. Although Bank Indonesia did have sufficient reserves to cover base money, since total reserves at the end of December 1997 stood at some $\$ 17$ billion; this amount, it should be noted, was far smaller than the total stock of private short-term debt. If foreign lenders refused to renew the short-term loans extended to Indonesian borrowers, foreign exchange would be withdrawn to repay these loans, shrinking the reserve base and forcing a sharp contraction in the money supply. That would of course have raised interest rates to possibly very high levels further weakening banks but now without a lender of last resort to prevent their collapse. If a broader definition of money was adopted the available reserves were clearly insufficient. ${ }^{31}$

These arguments against the currency board were seemingly disregarded but the government could not easily dismiss the crescendo of international criticism that broke as the likelihood that Indonesia would adopt a currency board grew stronger. Most important perhaps was a letter from Michel Camdessus, Managing Director of the IMF, to President Soeharto, which was leaked to the press. ${ }^{32}$ In the letter the IMF Managing Director declared that while the IMF had supported the establishment of currency boards in the past, it did not believe that the current conditions in Indonesia would allow the currency board to survive. The letter ended by recommending that the idea of a currency board be shelved, at least for a time, and concluded that "... if a currency board proposal were adopted, we would not be able to recommend to the IMF Board the continuation of the present program...." To emphasize the seriousness of that move the letter went on to note that "this would be a very unfortunate development, as it would shrink even further the reserve basis for the currency board and further undermine its very slim chances of success." Nevertheless the move to adopt a currency board seemed on track when Finance Minister Mar'ie Muhammad informed Parliament that the government was preparing the groundwork for the adoption of a currency board. But now came a string of phone calls from and hastily arranged visits by senior government officials from a num-

${ }^{31}$ Cf. Djiwandono, op cit., p. 68.

${ }^{32}$ Letter from Camdessus to President Soeharto. (February 11, 1998). 
ber of countries that had strong economic ties to Indonesia, including Japan, Germany, the UK, and the US, all urging President Soeharto to stick with the IMF program and to forgo the idea of a currency board. Eventually the government's resolve to adopt a currency board weakened and the idea was shelved but not before this issue ended the career of Governor Soedrajat Djiwandono. On February 17 Governor Soedrajat was summarily dismissed and while he had never publicly expressed any position on the currency board issue it seems likely that his concerns about the feasibility and effectiveness of this arrangement was final straw that led to his dismissal. ${ }^{33}$ Although various businessmen and even on occasion government officials would continue to raise the idea the immediate possibility of establishing a currency board had passed. ${ }^{34}$

Despite the economic turmoil that was increasingly accompanied by rising popular unrest, the economy began to show some signs of regaining stability. On February 23, Bank Indonesia raised interest rates and began to sell Sertifikates Bank Indonesia in an effort to bring base money under control. A week later seven commercial banks were closed and another seven banks, including three large state banks, were placed under the management of the Indonesian Bank Reconstruction Agency. Elections were held leading to the reelection of President Soeharto with Minister Habibie, as expected, as his Vice President. While these events passed with relatively little violence, on a less positive note, the new cabinet that took office in mid-March not only further reduced the role of the economic technocrats but clearly shifted power to a group very closely identified with the existing political regime and staffed by Ministers that were less inclined to carry through the reform program agreed upon with the IMF. Nevertheless the Fund quickly began to work with the new cabinet and on April 8 the government announced agreement on a Supplementary Memorandum of Economic and Financial Policies, effectively up-

\footnotetext{
${ }^{33}$ A number of other senior and experienced civil servants were also fired over the next few weeks. On March 6, Boediono, effectively Deputy Governor of Bank Indonesia, was dismissed, and around the same time Bambang Subianto was dismissed as head of IBRA. For a time it seemed that Finance Minister Mar'ie Muhammad would be headed for a similar fate but he survived for reasons that may never be know. Lloyd Kenward, "From the Trenches: The First Year of Indonesia's Crisis of 1997/98 as seen from the World Bank's Offices in Jakarta." (Unpublished, May 1999, p. 52.).

${ }^{34}$ For example on February 10, 1999, the Jakarta Post (the leading English language newspaper in Indonesia) reported that Amien Rais, leader of a major opposition party had indicated that Indonesia should reconsider using a currency board to help in rebuilding the devastated economy. Rais apparently commented on an article by Steve Hanke, Merton Miller and Christopher Culp in the Journal of Applied Corporate Finance that again raised the issue of whether Indonesia should adopt a currency board.
} 
dating the January agreement. In designing the new letter of intent the Fund tried to strengthen its position. Instead of a single disbursement of US\$3 billion to be released upon approval by the Board of the new program, the Fund substituted three disbursements of $\$ 1$ billion each, to be released at monthly intervals following satisfactory reports by review missions from the Fund.

The April 1998 monthly economic report (Laporan Bulanan Makroekonomi) reported that the currency had gained some $6.4 \%$ against the dollar for the month, even as other Asian currencies weakened, and showed fewer signs of extreme volatility. The inflation rate as measured by the consumer price index remained high but declined from the very sharp increases observed during the first quarter of 1998. While it was recognized that a number of special factors helped bring about these improvements they were undoubtedly helped by the announcement that the government concurred in the establishment of a Monetary Monitoring Committee, which included in addition to a representative from Bank Indonesia, representatives from the IMF, the US Treasury, and the Bundesbank. This was seen as a significant step in strengthening the central bank's independence since the committee was to monitor monetary developments and provide recommendations to safeguard the monetary targets of the stabilization program. In effect it provided a bulwark intended to insulate Bank Indonesia from the intrusion of political interest that in the past had often hampered effective monetary policy. Bank Indonesia quickly moved to bring the monetary situation under control by contracting the base money supply. One result was an improvement in the exchange rate and a reduction in the rate of inflation.

But despite this temporary respite the crisis was now set to enter its final stage. As inflation had gathered speed and as economic activities, especially construction, had ground to a halt, social unrest had spread. In early February 1998, mobs attacked shops, many owned by ethnic Chinese, in a number of the provinces, including the island of Java. These attacks not only disrupted the distribution system, as trucking firms became reluctant to move goods into the riot-affected areas, but the racial tone of the riots probably led to further capital flight on the part of the ethnic Chinese minority. It was with this background in mind that the monthly economic report, while noting the improvement in the general macroeconomic situation, expressed concerns that the government's com- 
mitment to eliminating energy subsidies in one step would not only reignite inflation but could further undermine social stability. The report strongly urged the government to consider eliminating all fuel subsidies slowly over an extended period of time. ${ }^{35}$ That advice was not heeded.

Indonesia, like many oil-exporting countries, had long struggled with the appropriate price for its domestic energy users and energy price controls were a major part of the government's long-standing economic and social policy stance. The government justified its pricing system by noting that the subsidy on kerosene was an important poverty alleviation tool even though numerous studies suggested otherwise. In fact the share of expenditure on kerosene by the poorest segment of the population was rather small and the subsidy was a particularly inefficient poverty alleviation tool because of the substantial leakage of kerosene not only to various transport activities, notably to diesel powered mini-buses and other diesel-powered machines, but also to offshore users. ${ }^{36}$ More difficult to justify was the fiscal subsidy provided to gasoline users, most of them in the upper income classes, although the extent of the subsidy varied as international prices fluctuated while the domestic price remained fixed. ${ }^{37}$

Given the commitment made to the IMF to eliminate the long-standing energy subsidies, numerous studies now began to look at the likely impact of such a move on the economy. For example, as a study undertaken in December 1997 noted “...any move to totally eliminate the subsidy on BBM [petroleum products] would have a very significant impact on the consumer price index." That report went on to suggest that "...even if there is political support for the large price increase for fuel products that are required to meet

35 Laporan Bulanan Makroekonomi (May 1998), A study undertaken in the Ministry of Finance suggested that the impact of single move to eliminate all fuel subsidies would create considerable inflationary pressure and suggested instead that the government rely on a series of stepped price increases to meet the IMF target.

36 In a study prepared by Steven Radelet and Benjamin Dennis, "Proposed BBM Price Schedule" it was noted that various studies put the expenditure share by poor families on kerosene at 2-3\% of total household expenditure. In 1992 it was estimated that a then proposed $27 \%$ increase in kerosene prices would reduce the purchasing power of the poor by approximately 0.6 to $0.8 \%$. (Memorandum 905/92/36) Economic Analysis Project, Ministry of Finance, Jakarta, Indonesia.

37 Thus when gasoline prices were adjusted in 1993, gasoline prices were raised sufficiently so that the use of motor fuels was effectively taxed, partly offsetting the environmental costs of motor vehicle use. Cf.

Joseph J. Stern, "Economic Performance and Deregulation." Memorandum 126/96/404. (October 4 1996) Economic Analysis Project, Ministry of Finance, Jakarta, Indonesia. A suggestion to adjust energy prices more frequently in line with changes in world oil prices was also put forward but never adopted so that in fact there had been no change in domestic energy prices between mid-1993 and early 1998. 
the IMF target, the resulting inflation surge would exceed the IMF inflation goal." 38 The study then concluded that "...the IMF condition that fuel subsidies be eliminated cannot be reconciled under any reasonable exchange rate assumption with the IMF assumption that inflation in 1998/99 will be held below 10\%." "39 Hence it was suggested that the fuel subsidies be eliminated through a more staggered approach. Admittedly reducing the subsidy over a period of a year, as was presumably permitted under the terms of the IMF agreement (see above), would be costly to the government budget even if it would reduce the inflationary spurt to be expected from a sudden elimination of all subsidies on energy.

On May 4, 1998, the government announced that energy prices would rise the following day. At one end of the product spectrum, gasoline prices were set to increase by some $71 \%$ while kerosene would see its price rise by $25 \%$. The basic electricity tariff would also be raised by some $20 \%$ with the added warning that further price increases would come later in the year. While government had raised energy prices in years past, often by substantial amounts, the decisions to increase energy prices so dramatically and so soon after the onset of the economic crisis was bound to raise concerns. Indeed the President was warned by members of the Cabinet and by senior army officers that the sudden increase in energy prices, following upon the turmoil caused by the depreciation of the rupiah and the rising unpopularity of the political regime, could lead to further demonstrations which the military might not be able to control. They all urged the president to postpone the fuel price adjustment for the time being. But the President rejected this advice indicating that the government had just raised the floor price for rice, an obviously popular move among parts of the rural populace. This he believed would cushion the negative impact of the energy price increase, as it had done in the past. Unfortunately this time events proved him wrong.

Student demonstrations had been increasing for some time. Security forces had let it be known informally that they would tolerate such activities as long as the demonstrations were restricted to the university campuses. But the demonstrations now became

\footnotetext{
38 Simon Kandel and Joseph J. Stern, “Proposed BBM Price Adjustment.” Memorandum 905/97/827. Economic Analysis Project, Ministry of Finance, Jakarta, Indonesia.

39 Ibid. It should be noted that when the standby agreement was under negotiation it seemed reasonable to assume that the exchange rate would stabilize around Rp.3,500/US\$. That assumption was no longer tenable by the end of the year when measures were under discussion to meet the IMF goal on fuel prices.
} 
more vocal and focused on the social implications of the fuel price increase. By May $7^{\text {th }}$ students began to ignore the Army's warnings and moved their demonstrations offcampus. On May $8^{\text {th }}$ Parliament, in a highly unusual move, demanded a review of the fuel price increases. On the following day, Soeharto, still confident that the situation would remain under control, departed for a G-15 summit meeting in Cairo. Events now moved with dramatic speed. On May $12^{\text {th }}$ four students were killed by snipers on the streets outside Trisakti University whose campus was on a main Jakarta thoroughfare and close to the exclusive residential areas where many of the elites lived. The death of the four students set off serious rioting over the next two days and led to numerous deaths in Jakarta and other major urban centers, accompanied by looting and the burning of banks and many Chinese owned businesses. The rapidly deteriorating security situation forced Soeharto to return from Cairo on May $15^{\text {th }}$ and announce a partial rollback of the fuel price increases. But by then, with the army having been called out to establish some measure of calm in Jakarta and other major urban centers that had been rocked by riots, the bitterness with the political regime had moved well beyond this single issue. Despite some maneuverings by Soeharto to regain some measure of political control and retain power his time was quickly running out. On May $20^{\text {th }}$ fourteen Cabinet Ministers, led by Coordinating Economic Minister Ginandjar Kartasasmita, informed the President that they would not participate in any new Cabinet appointed by the President. That evening General Wiranto, commander-in-chief, called on Soeharto to step down and which he did the following day. Vice President Habibie was immediately sworn in, effectively marking the end of the new order regime.

The crisis eases.

Although political upheaval had put all stabilization efforts on hold, as some measure of security and calm returned the IMF once again sent a delegation to Jakarta near the end of May to lay the ground work for renewed discussions between the new government and the IMF that began on June $8^{\text {th }}$. Under the guidance of the Coordinating Minister for the Economy, Ginandjar Kartasasmita, the talks progressed well and relations between the government and the IMF improved. While the economic crisis was far from over, the process of reform now began in earnest. To the surprise of many President Habibie and his cabinet worked effectively with the IMF and with Parliament that 
quickly passed numerous reform measures that had lagged under the previous regime. But what was less readily appreciated was the difference between legislating reform and actually changing societal behavior. That is a much longer and more complex process that is still ongoing. ${ }^{40}$

The Asian crisis took a severe toll on the Indonesian economy. As shown in Table 3, Indonesia's economy shrank more than that of any of the other Asian affected economies while its recovery from the depth of the crisis has been the slowest. ${ }^{41} \mathrm{Al}-$ though the economic recovery continues, the rate of growth has yet to recover the precrisis level. And economic growth has so far failed to reach a level where it creates sufficient employment for new entrants to labor force let alone allow for any reduction in existing under-employment. For a variety reasons - some domestic and some reflecting changes in the global economic and political outlook - foreign capital inflows, which powered much of the early growth of the Indonesian economy, have yet to recover and investment levels remain anemic, with the level of capital formation remaining some 10percentage points below pre-crisis levels. Equally disturbing, the composition of investment has shifted to property investment, which now takes up almost 80 percent of the total. Contrast this with investment in machinery and equipment which declined from 23 percent of total investment in 2000 to 18 percent in the first three quarters of 2003, a trend reflected in the 50 percent decline in machinery imports. Indeed it is private consumption, not investment that has now become the main source of growth, accounting for 91 percent of GDP growth in 2002 and for 83 percent in the first three quarters of $2003 .^{42}$

\footnotetext{
${ }^{40}$ Rodrik and Subramaniam note that while "....the quality of institutions ...is the only positive and significant determinant of income levels...institutional change is slow ... Adjustments that would sustainably improve development prospects cannot happen over a three to five year period... To believe otherwise risks the near certainty of expectations being unrealized." Dani Rodrik and Arvind Subramanian, "The Primacy of Institutions," in Finance and Development (June 2003).

${ }^{41}$ See also Appendix Figure A.

${ }^{42}$ Cf. "CGI Brief-Beyond Macroeconomic Stability. Report No. 27374, prepared by the World Bank Indonesia Field Office, December 2003.
} 


\section{Table 3}

Growth in GDP per capita

(Per cent per annum)

\begin{tabular}{|c|c|c|c|c|c|}
\hline$\underline{\text { Year }}$ & $\underline{\text { Indonesia }}$ & $\underline{\text { Korea }}$ & Malaysia & $\underline{\text { Philippines }}$ & Thailand \\
\hline$\overline{1995}$ & 5.96 & 7.83 & 6.85 & 2.22 & 7.99 \\
\hline 1996 & 6.69 & 5.70 & 7.40 & 3.45 & 4.84 \\
\hline 1997 & 3.10 & 3.98 & 4.89 & 2.85 & -2.35 \\
\hline 1998 & -15.06 & -7.57 & -9.54 & -2.72 & -11.33 \\
\hline 1999 & -0.68 & 9.88 & 3.33 & 3.95 & 3.75 \\
\hline 2000 & 3.38 & 8.36 & 5.93 & 1.87 & 3.36 \\
\hline 2001 & 1.22 & 2.90 & 3.42 & 2.31 & 0.84 \\
\hline $2002^{(a)}$ & 1.66 & & & & \\
\hline
\end{tabular}

Note: (a) Preliminary estimate from Biro Pusat Statistik Indonesia, Jakarta, Indonesia.

Source: International Monetary Fund (2002). International Financial Statistics. CD-Rom

The economic crisis also sharply raised poverty levels despite the considerable efforts by the Indonesian government and the World Bank to create an effective and wellfunded social safety net. As the methodology used to measure poverty changed after 1996, it is no longer possible to make direct comparisons to pre-crisis observations. One can only note that at the height of the crisis, in 1998, nearly a quarter of the population was counted as falling below the poverty line, a level of poverty last seen in 1981, although it must be emphasized again that these direct comparisons are at best indicative of changes in the poverty situation. As the economy began to recover the measured level of urban poverty began to decline and by 2001 had seemingly fallen to roughly pre-crisis levels although rural poverty levels remain high.

The sudden and severe collapse of the Indonesian economy, which had been held up as a model of successful economic reform raised the obvious question whether the collapse was truly a reflection of internal weaknesses, some of which may have been overlooked in the euphoria of the period of rapid growth, or whether the policy prescriptions recommended by the Fund and its supporters turned a possibly minor economic downturn into a major economic and political debacle. Critics of the IMF have focused on the initial standby agreement, which, it is argued, put into place a set of policies that contributed to the economic downturn. Although the stand-by agreement covered many specific 
items four broad issues are common elements in most of the criticism leveled at the IMF. $^{43}$

- First, the IMF forced the government to confront the weaknesses of the financial sector by closing 16 banks and commit itself to longer-term program of closing additional banks, merge the existing state banks, and strengthen the institutional, legal and regulatory framework for the financial system as a whole;

- Second, monetary policy was to be tightened to help stabilize the rupiah;

- Third fiscal policy was to achieve a public sector surplus of about $1 \%$ of GDP in both 1997/98 and 1998/99. This would be brought about by reducing or eliminating numerous subsidies including adjustments in the administered prices for electricity and fuel; and

- Fourth, numerous domestic monopolies were to be eliminated. ${ }^{44}$

Moreover, critics have also noted that many of the elements of the initial stand-by mirrored stabilization programs carried out by the IMF in different settings where the causes of the economic collapse were different from the Asian crisis and where these policy prescriptions may well have had some rationale. This argument claims that the IMF failed to understand the true cause of the Asian crisis, and especially as it played out in Indonesia, and simply used a standard set of tools to try and treat a vastly different economic problem. To some extent the IMF did use a standard set of analytic insights to help deal with the crisis but whether they were truly inappropriate for the Indonesian situation is more difficult to assess. A partial answer is found in addressing the four specific criticisms identified above.

First, did the closing of the 16, relatively small banks, set of the banking crisis? Was this policy step, taking at the insistence of the IMF, a serious mistake as some have argued or a necessary step towards longer-term reforms of the banking system? Even today the argument is difficult to disentangle. It is certainly true, as noted above, that a fairly

\footnotetext{
${ }^{43}$ Cf. Steven Radelet and Jeffrey Sachs (1998a) "The Onset of the East Asian Currency Crisis." NBER Working Paper No. 6680 (April); Steven Radelet and Jeffrey Sachs (1998b) "The East Asian Financial Crisis: Diagnosis, Remedies, Prospects." Brookings Papers on Economic Activity, 1998:1, pp. 1- 74; Jason Furman and Joseph Stiglitz (1998) "Economic Crisis: Evidence and Insights from East Asia." Brookings Papers on Economic Activity, 1998:2; as well as the IMF's own rebuttal to the critiques contained in the report by the Independent Evaluation Office, "Evaluation of the Role of the IMF in Recent Capital Account Crisis. Washington, DC: International Monetary Fund (April 2003). A succinct statement of the main lines of criticism is given in Jeffrey Sachs (1997) "The Wrong Medicine for Asia." The New York Times, November 3, 1997, page A23.

${ }^{44}$ Independent Evaluation Office, International Monetary Fund. "Evaluation of the Role of the IMF in Recent Capital Account Crisis: Country Annexes," Appendix A1-2, p. 54. (Washington, DC: April 11, 2003).
} 
widespread bank run was already well underway prior to the November actions. Hence the closing of the 16 banks did not precipitate the capital "flight to safety." The argument that the closing of the banks, including the closing of a bank owned by the second son of the President, signaled to the ethnic Chinese community that Soeharto's capacity to protect them was rapidly fading, and that they needed to seek safety elsewhere may well be correct but is not likely to be settled by appeal to economic arguments. And one should remember that some analysts argued that because only 16 banks were closed, while various clandestine broadsheets listed many more weak banks, creating a widespread feeling that most banks were unsound. Indeed the IMF program made it clear that additional banks would be closed and it would be difficult to argue that expectations on future bank closures did not play a part in the evolving banking crisis. If so it may well be that an earlier announcement of a limited deposit guarantee scheme would have mitigated some of the worst bank runs. But the IMF and other analysts felt that it was necessary to move quickly, rather than wait until agreement could be reached on some limited deposit guarantee scheme, so that a strong and clear signal could be sent to the international financial markets that a serious effort at bank reform was underway. In this view the benefits of speedy action outweighed the benefits of putting a deposit guarantee scheme in place.

Whatever the merits of that argument, actual events clearly undermined the signal on bank reform that might have come out of the initial bank closings. Bambang Trihatmodjo, second son of President Soeharto and a minority owner of one of the banks closed, was able to procure another banking license allowing him to open a bank on the same premises with the same staff albeit under a new name. Probosutedjo, half-brother to the President and sole owner of Bank Jakarta, together with Bambang Trihatmodjo initiated a suit against the Minister of Finance arguing that the bank closure were illegal. While the suit was quickly dropped, these actions could hardly have persuaded the international financial community that much progress in cleaning up the banking system was forthcoming. Moreover the Presidents own view that there should be no further bank closures in the near-term further eroded the immediate impact that the bank closure sought to gain.

Second, it can be argued that the Funds advocacy of a tight monetary policy would seem to run counter both to the standard countercyclical role that monetary policy plays 
during a recession in industrialized countries and to the traditional role of the central bank as a lender of last resort. The IMF position reflects a belief that a tight monetary stance can help prevent the exchange rate depreciation from being "passed through" to domestic prices and that by limiting the overshooting of the exchange rate depreciation; it can mitigate the adverse effects of the depreciation on the net worth of domestic financial institutions. In short, the IMF feared that an excessive currency depreciation would increase the insolvency of firms, most of which had severe currency mismatches and had borrowed short-term funds without hedging their loans, thus potentially magnifying the economic dislocations and output losses associated with the crisis. ${ }^{45}$ The critics of this traditional view argue that even if tight monetary policy had been successful in sustaining the value of the currency above what it would have been with a loser monetary policy, the tight monetary stance itself would have led to the very adverse outcomes the IMF sought to prevent. Some critics question whether tight monetary policy can ever be successful in defending the value of a currency in a crisis since the high rates interest rates that this requires will imperil the solvency of banks and firms, further reducing the likelihood that external debts will be serviced. Because of their adverse affect on credit risk the high interest rates will reduce the attractiveness of acquiring claims on the domestic economy, further weakening the exchange rate.

In a thoughtful analysis Montiel concludes that while the contrarian view cannot be dismissed out of hand, “...the empirical work on this issue does not speak with one voice. If there is one theme that runs consistently through the empirical work it is the absence of strong results not just for or against the contrarian view but also for the view that monetary policy has any consistent and systematic effect on the exchange rate in post-crisis situations. $" 46$

But here too actual events did not follow the IMF recommendation that interest rates be raised and kept high. Whatever the merits of the theoretical case, the fact remains that the government failed to follow a tight monetary policy so this IMF recommendation can hardly be blamed for the final debacle. As far back as November 17, 1997, the Fund in-

\footnotetext{
${ }^{45}$ See Peter J. Montiel, "Tight Money in a Post-Crisis Defense of the Exchange Rate: What Have We Learned?" - The World Bank Research Observer. Vol. 18(1) Spring 2003, pp. 1 - 25, for an excellent summary and analysis of this issue.

${ }^{46}$ Ibid. p. 20.
} 
formed the government that the gains seen after the signing of the first agreement were slipping away because monetary policy had been eased to quickly. Indeed by midNovember the overnight inter-bank rates were about $35 \%$, down from the $50 \%$ level reached just after the first agreement was signed. Throughout much of the latter half of 1997 monetary policy was relatively accommodating and interest rates, especially real interest rates, were never seriously raised. It was not until March 23, 1998 that the monetary authorities shifted to a much higher interest rates stance, significantly raising the rates on Sertifikates Bank Indonesia (SBI certificates). This step was immediately reflected in a drastic increase in the term deposits offered by commercial banks, although by then cumulative inflation for the period April 1997 - March 1998 stood at 34.2\% and the rupiah had depreciated by some $72 \%$ since the onset of the crisis, so that much of the damage to real economy had already been done. ${ }^{47}$ One is forced to conclude that the argument that tight monetary policy contributed to the collapse of the Indonesian economy is not nearly as strong as it has been made out.

Third, the recommendation that Indonesia adopt a more restrictive fiscal policy, aiming for a public sector budget surplus, is indeed more difficult to understand. Critics of the IMF argue that this position failed to recognize that Indonesia, like many of the other East Asian economies, had generally followed prudent fiscal policy and that large budget deficits were not, by any stretch of the imagination, a primary cause of the economic crisis. Before the onset of the crisis Indonesia had garnered a well-earned reputation for financial prudence based on its concept of a "balanced budget" so that in 1996 Indonesia had one of lowest ratios of government debt to GDP in the world, ranking below Switzerland and Norway. Admittedly this generally sound fiscal stand hid two problems. First, the government has increasingly used so-called off-budget expenditures to fund a number of activities, many of which, such as the development of a jet-plane, had very low economic returns. Moreover, despite the tax reforms carried out in the 1980s, which had introduced a modern tax system, there had been relatively little progress in raising tax revenues, closing loopholes, eliminating corruption in the tax offices, and raising the efficiency of government investments. Improvements in all of these areas were certainly

47 Laporan Bulanan Makroekonomi (Monthly Economic Report). Prepared by the Economic Analysis Unit, Ministry of Finance. April 1998, pp. 8, 12, and 18. 
worthwhile goals but whether they needed to be addressed at the onset of a major currency crisis is questionable. Indeed a strong case could be made that as the currency crisis began to affect the real economy, causing layoffs and reductions in real incomes and a reduction in tax revenues, government needed to raise expenditures on a variety of social safety net programs even as revenues fell off. And over time the IMF changed its focus, insisting less on the attainment of specific budget surplus targets and more on creating a long-term viable fiscal base. For example, the performance review carried out in July 1998 focused on "...efforts to eliminate the fiscal deficit over the medium-term..." and looked for steps to "...improving budgetary revenue performance and expenditure management. ${ }^{, 48}$

In order to reach the target budget surplus the IMF wanted a reduction or elimination of numerous subsidies including adjustments in the administered prices for electricity and fuel. ${ }^{49}$ Eliminating the numerous monopolies that had been established, mainly to benefit either members of the Soeharto family directly (such as the clove and citrus monopoly) or which created rents for other favored regime supporters (such as the monopoly on garlic and wheat imports and the controls on sugar imports) was a worthy goal. But once again one can question whether these issues had much to do with the immediate cause of the economic crisis and with the need to return some measure of stability to the economy. A review of the IMF program, prepared by members of the Economic Analysis Unit in the Ministry of Finance shortly after the first agreement had been signed, noted that"...the other major flaw in the program is that is seems to have ... [become a] vehicle for the IMF and the World Bank to urge on every structural and bureaucratic reform that they have ever imagined would be appropriate for Indonesia. While it is certainly true that actions need to be taken to promote real growth in light of the monetary shock that has occurred, it is not necessary or appropriate to completely reorganize the economy." The memorandum went on to note that “...pressure should be brought on the IMF to identify

${ }^{48}$ Indonesia - Third Review Under the Stand-by Arrangement Letter of Intent. (July 29, 1998) p. 6.

49 The actual language in the standby of November 1, 1997, is considerably more specific, calling for an adjustment in the "...administered prices of petroleum products and electricity before April 1, 1998, with a view to eliminating subsidies for these products." (p. 12). The IMF looked for this measure alone to make a significant contribution towards the required fiscal adjustment. 
those structural changes they believe are essential to the success of the program" ${ }^{, 50}$ because, as the report went on to say, carrying out such an ambitious reform program would be challenging under the best circumstances while in the midst of a serious economic crisis (which admittedly was just beginning at the time the report was written) it would extremely difficult to carry out a reform program of the type called for by IMF. Even so the report concluded that “...over a longer period of time, nearly all of the proposed changes should be made." 51

And that of course is the core of the problem: the IMF wanted to use the crisis to achieve what numerous Indonesian policy makers supported by numerous analysts, within the international community and within the government itself, had arduously worked for. By taking over this broad reform agenda but without fully appreciating what the reforms entailed, what political and social changes they implied, and what the capacity of the government was to manage such rapid economic change, the IMF not only weakened the focus of its own agenda but in the end undermined the political structure that had governed Indonesia for over 40 years. While the political change that was put in motion would have come sooner or later, a slower reform process might have achieved the same goals with less collateral damage. In a recent book Fareed Zakaria summarized what happened as follows:

"Although they were not entirely to blame, the IMF and the U.S. government demanded immediate and radical reforms in Indonesia during its 1998 crisis, thereby helping to delegitimize and topple the government. Had they recognized the political instability these reforms would produce, they might have moderated their demands and made do with a more incremental approach. Soeharto was running a flawed regime, but one that had achieved order, secularism, and economic liberalization - an impressive combination in the Third World. Most important, nothing better was available to replace it. Gradual political reform rather than wholesale revolution would have been preferable, certainly for the average Indonesian, who one assumes was the intended beneficiary of Western policies." 52

\footnotetext{
50 Joseph J. Stern, Han Herderschee, et al., "Comments on the IMF Program" memorandum number 1997646r-109, p. 1. Economic Analysis Project, Ministry of Finance, October 18, 1997.

${ }^{51}$ Ibid.

52 Fareed Zakaria. The Future of Freedom: Illiberal Democracy at Home and Abroad. New York: W.W. Norton and Company (2003) p. 118.
} 


\section{Appendix A}

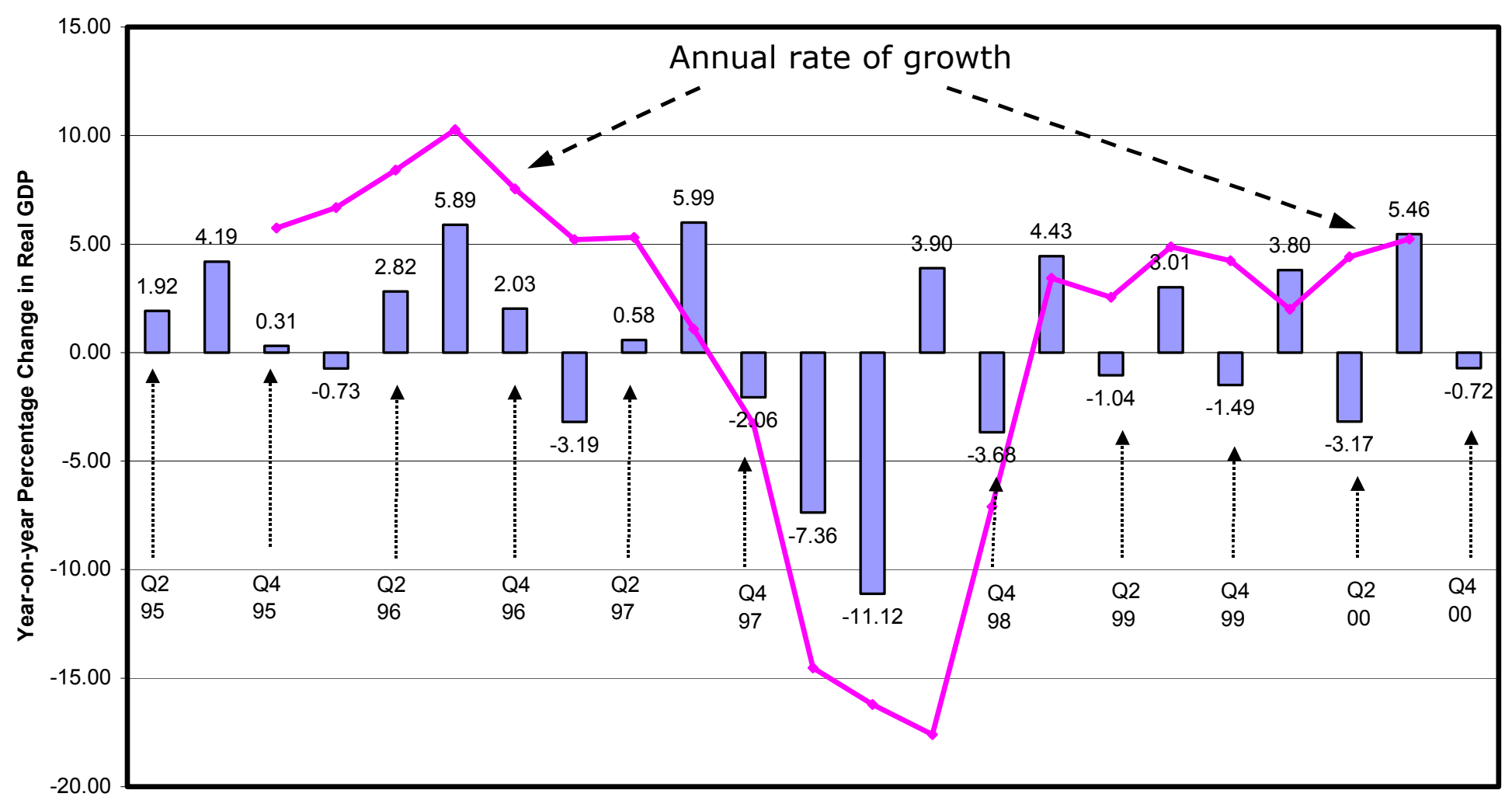


Appendix B

Number of People Below the Poverty Line

(Per cent)

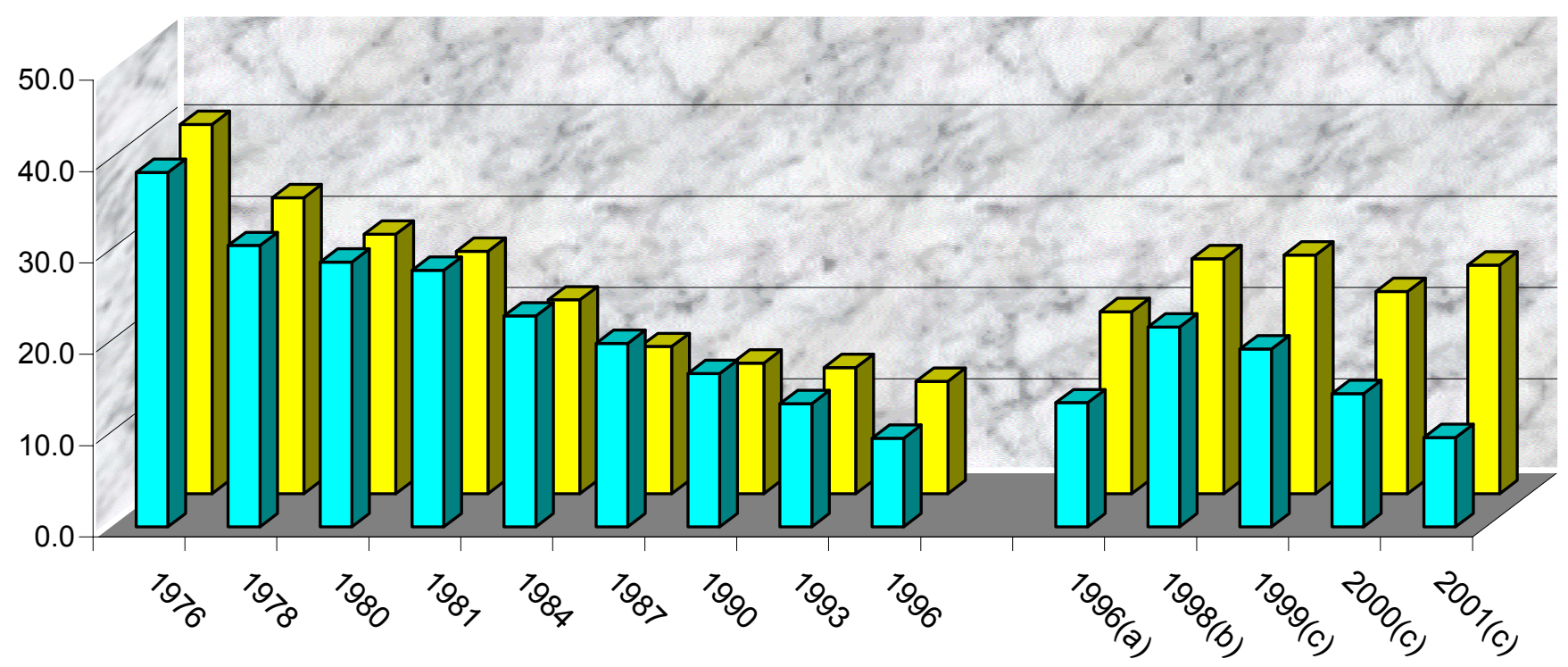

$\square$ Urban poverty $\square$ Rural poverty

Notes: (a) All data for 1996-2001 in the second part the chart uses Biro Pusat Statistik 1998 "new" definition of the poverty line.

(b) Based on December 1998 Sussenas.

(c) Based on February (regular) 1999 Sussenas. 


\section{Chronology of Events 1997}

\begin{tabular}{|c|c|c|}
\hline No. & Date & Event \\
\hline 1. & 11-Jul-97 & Bank Indonesia widens the exchange rate band from $8 \%$ to $12 \%$. \\
\hline 2. & 14-Aug-97 & Bank Indonesia abandons crawling peg system and floats the rupiah. \\
\hline 3. & 20-Aug-97 & $\begin{array}{l}\text { The rupiah falls below the Rp } 3,000 / \mathrm{US} \$ \text {. Concerned about the weakness of the } \\
\text { rupiah, Bank Indonesia raises the interest sharply and drains liquidity from the sys- } \\
\text { tem. The rupiah responds by appreciating to Rp. } 2,700 / \mathrm{US} \$ \text {. }\end{array}$ \\
\hline 4. & 10-23-Sept-97 & Interests rates are lowered. \\
\hline 5. & 8 -Oct-97 & Indonesia requests assistance from IMF. \\
\hline 6. & $\begin{array}{l}31-\text { Oct-97 to } 1- \\
\text { Nov-97 }\end{array}$ & $\begin{array}{l}\text { Indonesia reaches agreement with the IMF and a package comprising US } \$ 43 \text { bil- } \\
\text { lion. As part of the IMF package to strengthen the financial sector and to restore } \\
\text { confidence in the Indonesian economy, the government agrees to close } 16 \text { ailing } \\
\text { banks immediately with the government providing loans of some Rp } 2.3 \text { trillion } \\
\text { (US\$ } 697 \text { million) for repayments of deposits of up to Rp } 20 \text { million/depositor. In- } \\
\text { terest rates in the intra-bank market nearly double and the Jakarta Inter-Bank Over- } \\
\text { night Rate }(J I B O R) \text { reaches } 30 \% \text {. Interest rates in the morning and afternoon mar- } \\
\text { kets reach } 60 \% \text {. }\end{array}$ \\
\hline 7. & 08-Nov-97 & $\begin{array}{l}\text { Soeharto issues decree allowing the implementation of } 15 \text { projects, which had pre- } \\
\text { viously been put under "review" or postponed. The decree is widely perceived as } \\
\text { back tracking from earlier commitments. }\end{array}$ \\
\hline 8. & 21-Nov-97 & $\begin{array}{l}\text { South Korean won under renewed pressure. Trading is stopped for the third con- } \\
\text { secutive day. The halt comes just half an hour after the market opened, when the } \\
\text { local currency reached the limit of the widened band of } 10 \% \text { of the allowed daily } \\
\text { fluctuation. The won closed at } 1,139 / \mathrm{US} \$ \text {. Seoul is rumored to have asked the } \\
\text { IMF for assistance. }\end{array}$ \\
\hline
\end{tabular}




\section{Chronology of Events 1997}

No. Date

Event

9. 09-Dec-97 Rumors about Soeharto's health emerge. After a trip to South Africa, Canada (APEC meetings) and Saudi Arabia. Soeharto's doctors order him to rest for ten days. He is forced to cancel trip to Iran for a meeting of the Organization of Islamic Countries is to be held

10. 12-Dec-97 The announcement that Soeharto will not attend the informal ASEAN meeting in

Kuala Lumpur, Malaysia sends the currency and stock market downward. The rupiah closes at Rp 5,015/US\$, the stock market index closes at a four year low.

11. 31-Dec-97 Government announces that four state banks (BBD, BDN, Bapindo, Bank Exim) will merge in mid-1998. Indonesia's Ministry of Trade and Industry bans all exports of crude palm oil for the first three months of 1998 while hefty interventions by Bank Indonesia boost the rupiah to Rp 4,600/US\$, the value used to settle many end of year corporate accounts. 


\section{Chronology of Events 1998}

\begin{tabular}{ccc} 
No. & Date & Event \\
\hline 1. & 2-Jan-98 & $\begin{array}{l}\text { Rupiah falls to Rp 6,200/US\$, suggesting that Bank Indonesia had maintained an artificially strong } \\
\text { exchange rate for year-end accounting purposes. }\end{array}$
\end{tabular}

2. 6-Jan-98 Indonesia unveils its 1998/99-draft budget that assumes revenue and expenditure growth of 31.1\% over the previous budget while GDP is assumed to grow by $4 \%$, with inflation to be kept below $10 \%$. The assumptions are perceived as unrealistic and the rupiah weakens significantly.

\begin{tabular}{ccl}
\hline 3. & 15-Jan-98 & 2nd IMF package announced. \\
\hline 4. & 20-Jan-98 & $\begin{array}{l}\text { President Soeharto hints at Habibie as potential Vice President. The rupiah falls below Rp } \\
\text { 10,000/US\$ on January 21. }\end{array}$ \\
\hline 5. & 23-Jan-98 & $\begin{array}{l}\text { Indonesia presents a revised budget sticking to the figures agreed to with the IMF. The budget ex- } \\
\text { pects zero growth in FY 98/99 and assumes 20\% inflation and an exchange rate of Rp 5,000/US\$. } \\
\text { The rupiah ends the day at Rp 12,000/US\$. }\end{array}$ \\
\hline 6. & 27-Jan-98 & $\begin{array}{l}\text { Announcement of the bank guarantee. Establishment of IBRA (Indonesia Bank Reconstruction } \\
\text { Agency). }\end{array}$ \\
\hline 7. & 2-Feb-98 & $\begin{array}{l}\text { Rumors that a currency board may be established first surface. Strong speculation in the foreign } \\
\text { exchange market. }\end{array}$ \\
\hline 8. & 9-Feb-98 $\begin{array}{l}\text { Growing unhappiness over Soeharto's handling of the crisis leads to a signature campaign to re- } \\
\text { place him. Soeharto says he will announce new steps on the exchange rate, giving the first hint, } \\
\text { that a fixed currency system might be implemented. A curfew is imposed on Sulawesi after a series } \\
\text { of riots. }\end{array}$ \\
\end{tabular}




\section{Chronology of Events 1998}

No. Date Event

9. 11-Feb-98 Michael Camdessus, president of the IMF, sends a message to Soeharto informing him that the IMF opposes the idea of a currency board. "In the present circumstances, as a matter of fact, if a currency proposal were adopted, we would not be able to recommend to the IMF Board the continuation of the present program because of the risk to the Indonesian economy." Finance Minister Mar'ie Muhammad tells parliament that the government is preparing the groundwork for a currency board system. The rupiah strengthens to Rp 7,200/US\$.

\begin{tabular}{|c|c|c|}
\hline 10. & 17-Feb-98 & $\begin{array}{l}\text { President Soeharto replaces Bank Indonesia Governor Soedradjad Djiwandono with is Sjahril } \\
\text { Sabirin who is widely perceived as being supportive of the currency board idea while Djiwandono } \\
\text { was understood not to favor it, although he never publicly said so. }\end{array}$ \\
\hline 11. & 23-Mar-98 & $\begin{array}{l}\text { Bank Indonesia raises interest rates and starts selling SBIs in an attempt to get base money under } \\
\text { control. }\end{array}$ \\
\hline 12. & 4-Apr-98 & $\begin{array}{l}\text { Minister of Finance announces the suspension of seven commercial banks and the placing of another } \\
\text { seven banks under the management of IBRA. The latter group includes three large banks (Bank } \\
\text { Ekspor-Impor Indonesia, Bank Danamon Indonesia, Bank Dagang Nasional Indonesia). }\end{array}$ \\
\hline 13. & 4-May-98 & $\begin{array}{l}\text { Government announced increase in fuel and electricity prices. As of May } 5 \text {, gasoline prices are to } \\
\text { rise by } 71 \% \text {, kerosene by } 25 \% \text {, other product prices somewhere in between. The basic tariff for } \\
\text { electricity will be raised in May (by } 20 \% \text { ) and by further amounts in August and November. }\end{array}$ \\
\hline 14. & $5 / 12-14 / 98$ & $\begin{array}{l}\text { Police shoot Trisakti University, Jakarta, students who broke out of the campus, taking their protest } \\
\text { to the street. The following day severe riots take place in Jakarta and the army is finally called out } \\
\text { to restore order. Many buildings in the Chinese inhabited areas of town are burned and stores } \\
\text { looted. }\end{array}$ \\
\hline 15. & 21-May-98 & Soeharto steps down and Vice President Habibie is sworn in as President. \\
\hline
\end{tabular}




\section{Chronology of Events 1998}

\begin{tabular}{|c|c|c|}
\hline No. & Date & Event \\
\hline 16. & 17-Jun-98 & $\begin{array}{l}\text { Rupiah closes at Rp } 16,700 / \text { US\% after trading below Rp } 17,000 / \text { US } \$ \text { during the day. However the } \\
\text { weakness of the rupiah during June appears to be primarily the result of a management error by } \\
\text { Bank Indonesia. On June } 8, \text { BI told commercial banks to settle inter-bank loans and trade-finance } \\
\text { arrears before June } 11 \text {. Although BI quickly corrects its announcement, extending the deadline to } \\
\text { June } 30 \text { as stipulated in the Frankfurt agreements, the initial instructions caused substantial dollar } \\
\text { demand by commercial banks contributing to the weakness of the currency. }\end{array}$ \\
\hline 17. & 28-Jun-98 & 4th IMF agreement signed. \\
\hline 18. & 20-Jul-98 & $\begin{array}{l}\text { IMF decides to resume lending to Indonesia and to approve the immediate release of US\$ } 1 \text { billion } \\
\text { of balance of payment support. }\end{array}$ \\
\hline 19. & 29-Jul-98 & Consultative Group for Indonesia meets and pledges support. \\
\hline 20. & 21-Aug-98 & Liquidation of BDNI, BUN, and Bank Modern. \\
\hline 21. & 8-Sep-98 & $\begin{array}{l}\text { Fears of social unrest, triggered by further demonstrations in Jakarta and Surabaya cause the ex- } \\
\text { change rate to fall. }\end{array}$ \\
\hline 22. & 29-Sep-98 & Introduction of the bank recapitalization program. \\
\hline 23. & $\begin{array}{l}\text { Nov. } 11- \\
\text { Dec. } 31 .\end{array}$ & $\begin{array}{l}\text { Demonstrations and violent clashes between demonstrators and security personnel surrounding the } \\
\text { MPR session. }\end{array}$ \\
\hline
\end{tabular}

